\title{
Chicken of the Woods (Laetiporus sulphureus species complex) ${ }^{1}$
}

\author{
Brianna Benitez, Claudia A. Paez, Matthew E. Smith, and Jason A. Smith ${ }^{2}$
}

\section{Summary}

Members of the Laetiporus sulphureus (Bull.) Murrill species complex, also known as "chicken of the woods," are wood-decay fungi that are widely distributed in North America. All of the species of the "chicken of the woods" group cause brown rot in a variety of tree host species, and this brown rot can cause wood to lose its structural integrity and turn powdery. Based on a combination of morphological characteristics, mating studies, and molecular data, mycologists have distinguished five distinct species in North America: L. conifericola, L. cincinnatus, L. gilbertsonii, L. huroniensis, and L. sulphureus s.s. Fruiting bodies in this group can be recognized by their bright yellow-orange colors and their soft, suede-like texture.

\section{Introduction}

Species in the Laetiporus sulphureus species complex, also known as "chicken of the woods" mushrooms, are wooddecay fungi that cause brown rot within the heartwood of their tree hosts. These fungi form large fruiting bodies without an obvious stem (stipe), and they are sometimes referred to as "conks," "brackets," or simply "mushrooms." The common name "chicken of the woods" is given to some species in this group because they are tasty edible mushrooms. Several Laetiporus species have been harvested to use as food colorants, to dye natural products such as wool, and for human consumption (Bessette and Bessette
2001; Davoli et al. 2005). Species in this group typically cause rot in the main trunk of the tree but can also be found in roots and branches (Schwarze et al. 2000). Members of the Laetiporus sulphureus species complex are most common in hardwood host trees (especially on species of Quercus [oaks] and Prunus spp. [cherry]) but also can be found associated with some conifers (Gilbertson and Ryvarden 1986; Schwarze et al. 2000; Burdsall and Banik 2001). These fungi can infect both living and nonliving host trees. In urban settings, infection usually occurs through pruning cuts, bark injuries, or injured roots (Downer and Perry 2019). Laetiporus species belong to the family Laetiporaceae, which also includes several other genera of wood-decay fungi.

\section{Morphology}

The Laetiporus sulphureus species complex has distinct morphological characters that can be used to distinguish this group from other related fungi. The fruiting bodies are usually found from late summer through the fall directly on tree trunks or sometimes on old stumps or injured roots (Schwarze et al. 2000). The fruiting bodies can vary in color from a bright yellow to orange (Figure 1 and Figure 2), and they have a pore layer that is white to lemon yellow. They usually do not have a stipe but occasionally can have a very short stipe at the base where they are attached to the host tree. These fungi have smooth, white basidiospores (sexual

1. This document is PP358, one of a series of the Plant Pathology Department, UF/IFAS Extension. Original publication date October 2020. Visit the EDIS website at https://edis.ifas.ufl.edu for the currently supported version of this publication.

2. Brianna Benitez, graduate student, Doctor of Plant Medicine program; Claudia A. Paez, graduate student; Matthew E. Smith, associate professor, Plant Pathology Department; and Jason A. Smith, associate professor, School of Forest Resources and Conservation; UF/IFAS Extension, Gainesville, FL 32611.

The Institute of Food and Agricultural Sciences (IFAS) is an Equal Opportunity Institution authorized to provide research, educational information and other services

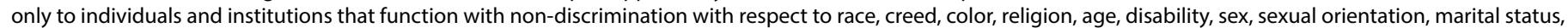

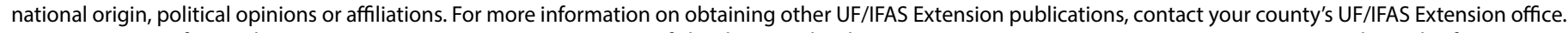
U.S. Department of Agriculture, UF/IFAS Extension Service, University of Florida, IFAS, Florida A \& M University Cooperative Extension Program, and Boards of County Commissioners Cooperating. Nick T. Place, dean for UF/IFAS Extension. 
spores) that are ovoid to ellipsoid and only visible under a light microscope (Gilbertson 1981; Murrill 1904). Each fruiting body starts as a small nodule on the host, and as it grows, it expands to create a fan-shaped shelf (Figure 1). Fruiting bodies typically grow in clusters, and they often grow overlapping one another in layers, like roof shingles on a house (Figure 2 and Figure 3) (Schwarze et al. 2000). Older specimens fade from orange or orange-yellow to a tan or white (Schwarze et al. 2000). Fruiting bodies have a soft and suede-like texture when young, but they tend to harden and become crumbly with age. The white-colored spore prints can be obtained by placing the cap of the fruiting body on a piece of paper with a bowl on top to retain moisture.

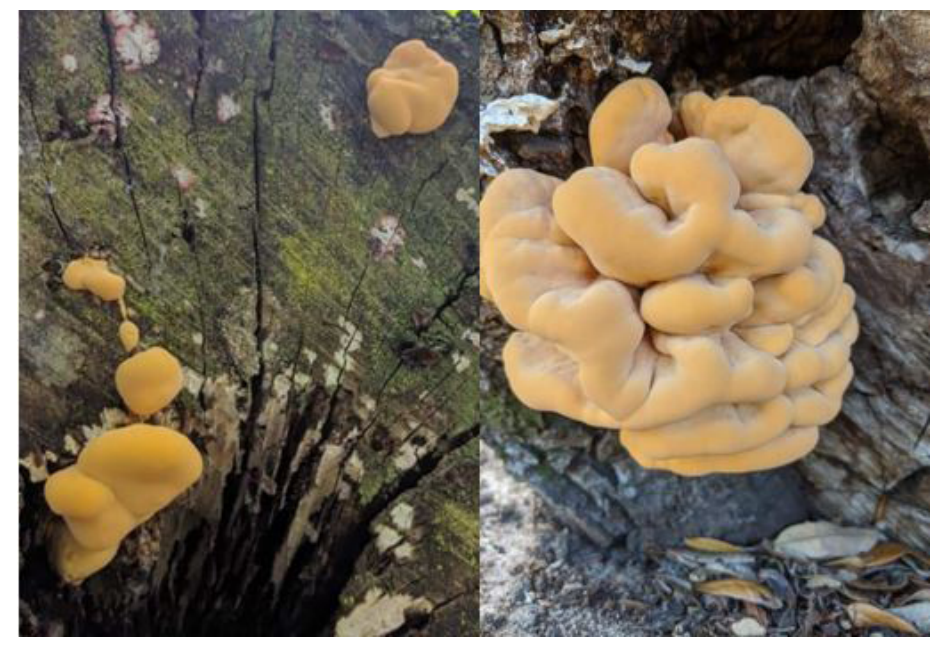

Figure 1. Young fruiting bodies of the Laetiporus sulphureus species complex. Gainesville, Florida.

Credits: Curtis Peyer

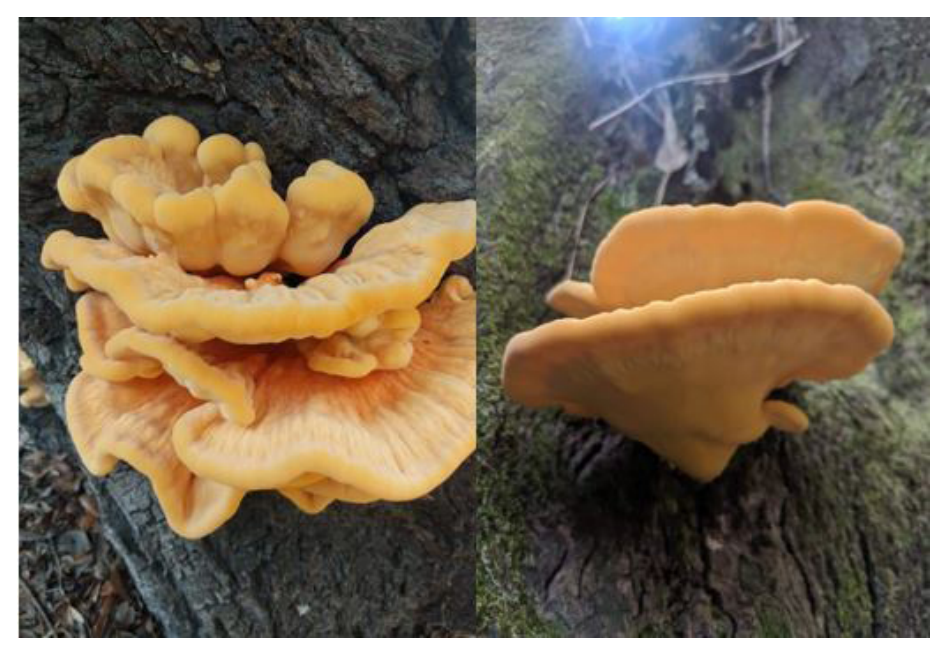

Figure 2. Mature fruiting bodies of Laetiporus sulphureus species complex. Gainesville, Florida.

Credits: Curtis Peyer

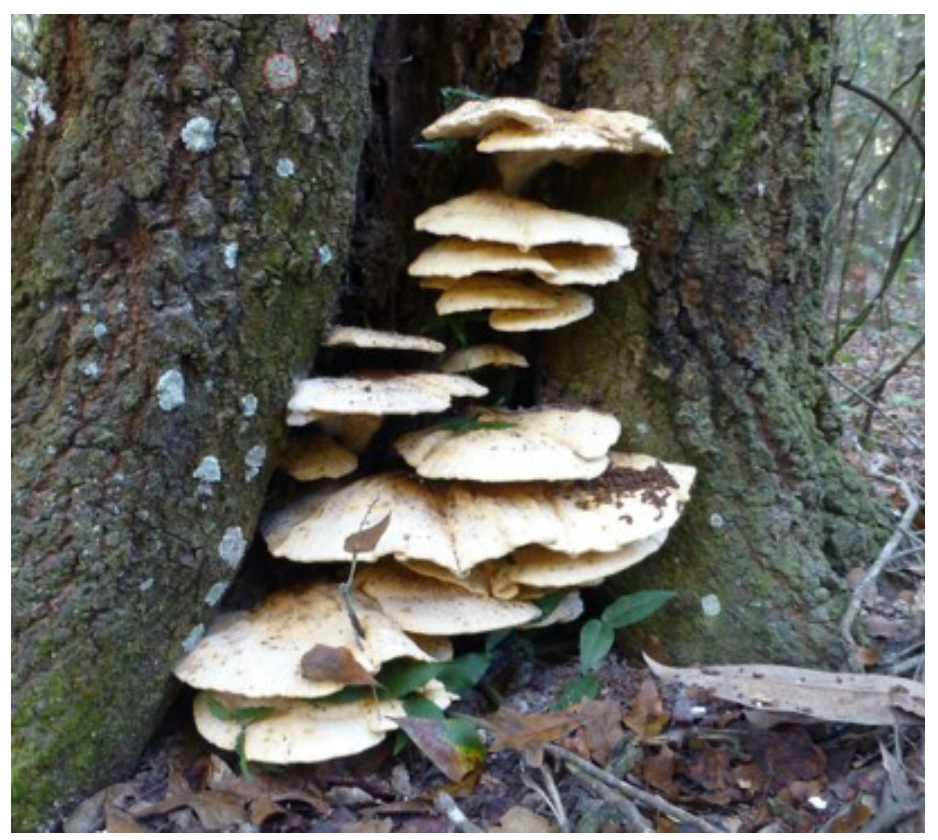

Figure 3. Old fruiting bodies of Laetiporus sulphureus species complex. Gainesville, Florida.

Credits: Sarah Prentice

\section{Taxonomy}

Taxonomy of the species in the Laetiporus sulphureus species complex is confusing because the related species are all very similar to each other. In the past, it was common to use the name L. sulphureus for any bright orange, poroid mushroom growing in fan-shaped clusters on wood (Gilbertson 1981; Murrill 1904). However, molecular and mating compatibility tests distinguished five well-supported species that are evolutionarily distinct from each other: L. conifericola, L. cincinnatus, L. gilbertsonii, L. huroniensis, and L. sulphureus in North America (Banik et al. 1998; Burdsall and Banik 2001; Lindner and Banik 2008). Some of the species differ in the color of the pore tissue. For example, $L$. cincinnatus and L. gilbertsonii have cream to white pores, whereas the other species have bright yellow-orange pores. Another important difference is that L. cincinnatus is the only species that typically emerges directly from the soil (i.e., it is attached to decayed roots that remain buried) and not from a log aboveground or from the base of a tree. In Florida, three species within the Laetiporus sulphureus species complex have been reported: L. sulphureus (the original species), L. gilbertsonii (Bessette et al. 2019), and L. cincinnatus (MyCoPortal 2020). However, L. gilbertsonii is the only species that has been confirmed with DNA sequences from Florida specimens (Lindner and Banik 2008). Further study of L. cincinnatus in Florida is needed to determine how similar it is to collections from other parts of North America (Lindner and Banik 2008). 


\section{Edibility}

Members of the Laetiporus sulphureus species complex are all called by the common name "chicken of the woods" because the fruiting bodies have a chewy texture and pleasant flavor that is similar to chicken when they are thoroughly cooked and eaten. Raw or undercooked Laetiporus mushrooms have been reported to cause gastrointestinal problems, and at least some individuals are allergic to "chicken of the woods," so these fungi should be consumed with caution. Laetiporus is also highly sought after for its antioxidant properties, and it is so desired that large-scale production is being considered in order to harvest it in larger quantities (Pleszczyńska et al. 2013). Members of the public should never consume wild mushrooms that they cannot positively identify as edible. When in doubt, throw it out!

\section{Signs and Symptoms on the Wood of Host Trees}

- Wood begins to look discolored, usually reddish or yellow.

- Wood plasticity increases and the wood easily crumbles.

- Yellow-orange fan-shaped fruiting bodies emerge near injury sites or at the base of the tree.

\section{Ecology}

Members of the Laetiporus sulphureus species complex cause brown rot decay of wood by selective degradation of cellulose and hemicellulose. The fruiting bodies develop in summer and fall, but the mycelium (the microscopic filaments that constitute the body of the fungus) are present throughout the year (Gilbertson and Ryvarden 1986). Species in the Laetiporus sulphureus species complex cause heart rot in both hardwoods and conifers (Blanchette 1991). Brown rot decay has an important role in forest ecosystems because residues of this type of decay persist in the soil for a long time and therefore retain water and decrease the loss of nutrients via leaching (Gilbertson 1981). The cavities caused by this type of decay are also important nesting sites for various wildlife species (Gilbertson 1981; Gilbertson and Ryvarden 1986).

\section{Management}

Trees in an urban setting that are suspected to have been colonized by members of the Laetiporus sulphureus species complex should be inspected and assessed as potential hazard trees by an ISA-certified arborist. Because members of the Laetiporus sulphureus species complex can weaken a tree, the tree may need to be removed, but an arborist can help provide a risk assessment. In a natural setting, it may be more appropriate to leave the tree without management because Laetiporus and other wood-decay fungi can be important components of our native ecosystems.

Once the fruiting bodies of a Laetiporus have been seen on a tree, it is too late to prevent the establishment of the fungus. To prevent additional harmful impacts to a decaying tree, we recommend following the advice outlined in Downer and Perry (2019): 1) properly prune branches to promote balanced branching structure, 2) remove dead or diseased limbs (particularly if they could endanger people or structures), and 3) prevent injuries to the bark or branches.

\section{References}

Banik, M. T., H. H. Burdsall Jr., and T. J. Volk. 1998. "Identification of Groups within Laetiporus sulphureus in the United States Based on RFLP Analysis of the Nuclear Ribosomal DNA." Folia Cryptog Estonica 33:9-14.

Bessette, A. E., A. F. Bessette, and D. P. Lewis. 2019. Mushrooms of the Gulf Coast States: A Field Guide to Texas, Louisiana, Mississippi, Alabama, and Florida. University of Texas Press.

Bessette, A. R., and A. E. Bessette. 2001. The Rainbow beneath My Feet: A Mushroom Dyer's Field Guide. Syracuse University Press.

Blanchette, R. A. 1991. "Delignification by Wood-Decay Fungi." Annual Review of Phytopathology 29 (1): 381-403.

Burdsall, H. H., Jr., and M. T. Banik. 2001. “The Genus Laetiporus in North America." Harvard Papers in Botany 6 (1): 43-55.

Davoli, P., A. Mucci, L. Schenetti, and R. W. Weber. 2005. "Laetiporic Acids, a Family of Non-carotenoid Polyene Pigments from Fruit-Bodies and Liquid Cultures of Laetiporus sulphureus (Polyporales, Fungi)." Phytochemistry 66 (7): 817-823.

Downer, J. A., and E. J. Perry. 2019. "Wood Decay Fungi in Landscape Trees" http://ipm.ucanr.edu/PMG/PESTNOTES/pn74109.html\#MANAGEMENT. Accessed April 30,2020 .

Gilbertson, R. L. 1981. "North American Wood-Rotting Fungi That Cause Brown Rots." Mycotaxon 12 (2): 372-416. 
Gilbertson, R. L., and L. Ryvarden. 1986. North America Polypores. Vol. I: Abortiporus - Lindtneria. Oslo: Fungiflora A/S.

Lindner, D. L., and M. T. Banik. 2008. "Molecular Phylogeny of Laetiporus and Other Brown Rot Polypore Genera in North America." Mycologia 100 (3): 417-430.

Murrill, W. A. 1904. “The Polyporaceae of North AmericaIX. Inonotus, Sesia and Monotypic Genera." Bulletin of the Torrey Botanical Club 31 (11): 593-610.

MyCoPortal. 2020. http://mycoportal.org/portal/index.php. Accessed July 2020.

Pleszczyńska, M., A. Wiater, M. Siwulski, and J. Szczodrak. 2013. "Successful Large-Scale Production of Fruiting Bodies of Laetiporus sulphureus (Bull.: Fr.) Murrill on an Artificial Substrate." World Journal of Microbiology \& Biotechnology 29 (4): 753-758. https://doi.org/10.1007/s11274-012-1230-z

Schwarze, F. W. M. R., J. Engels, and C. Mattheck. 2000. Fungal Strategies of Wood Decay in Trees.

Berlin: Springer. 70-72. https://books.google.com/ books?id=LZssbJ6g6PUC\&pg=PA73 